\title{
Technè
}

La science au service de l'histoire de l'art et de la préservation des biens culturels

$48 \mid 2019$

Les couleurs de l'Antique

\section{Investigations of a Gandharan stucco head of the Buddha at the Victoria and Albert Museum (IM.} 3-1931)

Recherches sur une tête de Bouddha en stuc du Gandhara conservée au Victoria \& Albert Museum (inv. IM.3-1931)

Giovanni Verri, Christian Luczanits, Victor Borges, Nick Barnard and John Clarke

\section{OpenEdition}

\section{Journals}

Electronic version

URL: https://journals.openedition.org/techne/2792

DOI: 10.4000/techne.2792

ISSN: 2534-5168

\section{Publisher}

C2RMF

\section{Printed version}

Date of publication: 31 December 2019

Number of pages: 136-149

ISBN: 978-2-11-152831-4

ISSN: 1254-7867

\section{Electronic reference}

Giovanni Verri, Christian Luczanits, Victor Borges, Nick Barnard and John Clarke, "Investigations of a

Gandharan stucco head of the Buddha at the Victoria and Albert Museum (IM.3-1931)", Technè

[Online], 48 | 2019, Online since 01 July 2021, connection on 02 April 2022. URL: http://

journals.openedition.org/techne/2792 ; DOI: https://doi.org/10.4000/techne.2792

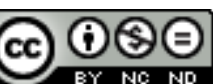

La revue Technè. La science au service de l'histoire de l'art et de la préservation des biens culturels est mise à disposition selon les termes de la Licence Creative Commons Attribution - Pas d'Utilisation Commerciale - Pas de Modification 4.0 International. 


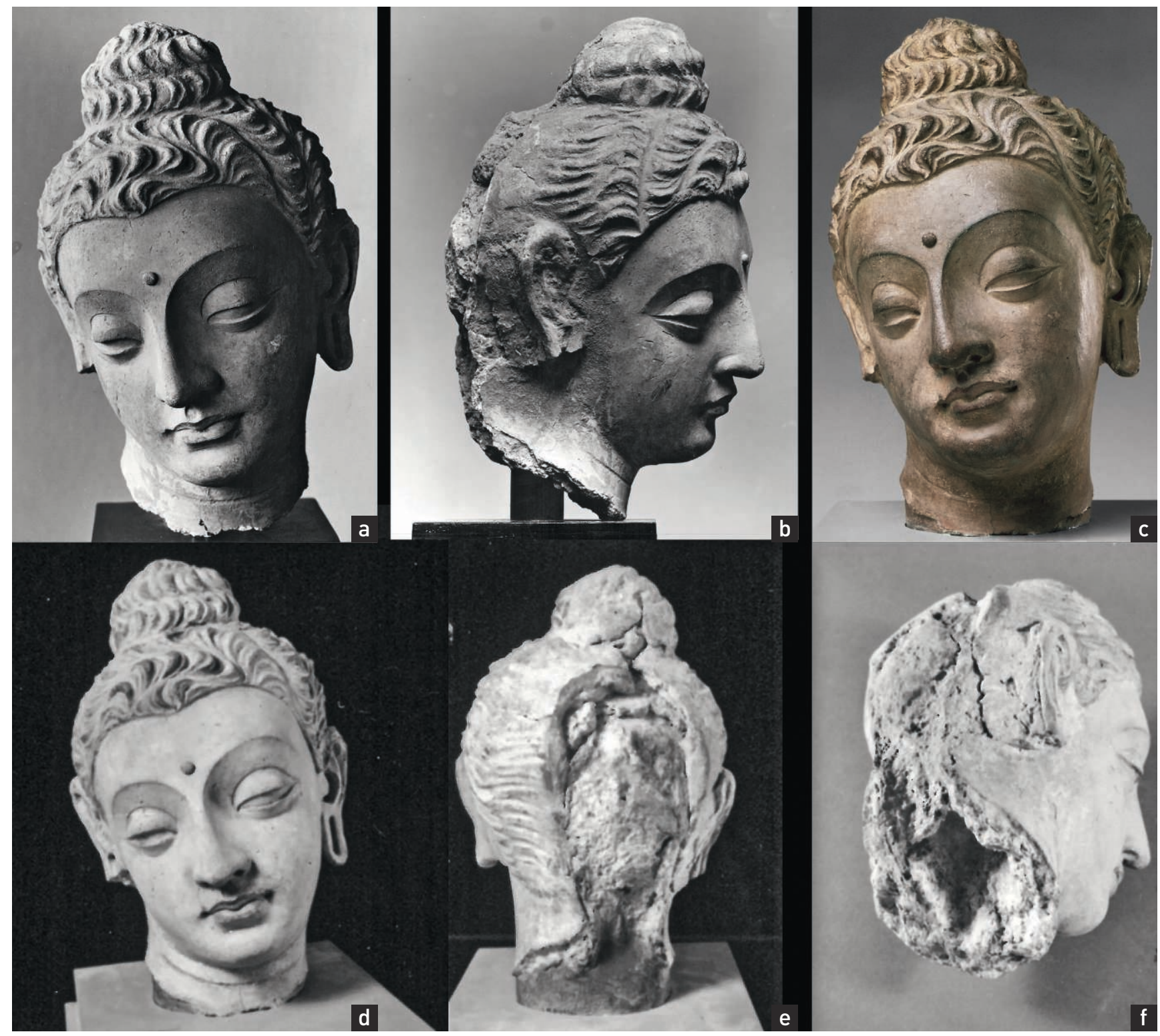

Fig. 1 a-f. a and b. The IM.3-1931 head mounted on a black stand. The dowel in the neck runs parallel to the neck and gives the head a pronounced downward gaze (negative number 66113 and 66114, respectively; V\&A, 1931). Burial deposits are still visible on and around the right ear; c. The head before the cleaning in the late 1980s (pre-1988; V\&A, 2017); d and e. The head after cleaning and mounted on a light base, with dark plaster connecting the base to the lower portion of the neck (1988?); $f$. The interior layers of the head, following the removal of a copper dowel (1988; V\&A, 2017). () Victoria and Albert Museum, London. 
Giovanni Verri

Christian Luczanits

Victor Borges

Nick Barnard

John Clarke

\section{Investigations of a Gandharan stucco head of the Buddha at the Victoria and Albert Museum (IM.3-1931)}

Recherches sur une tête de Bouddha en stuc du Gandhara conservée au Victoria \& Albert Museum (inv. IM.3-1931)

Abstract. This study presents the results of a technical and art historical study of an important Gandharan head from the Victoria and Albert Museum. For several years, the head has played an important role in the history of Gandharan art, because of its high aesthetic qualities. However, the head has received limited scholarly attention since its first display in the 1930s. This study reviewed the head's physical, curatorial and conservation history and determined its construction using non-invasive and non-contact investigative techniques (technical imaging, FTIR, $X R F$ and FORS). The support consists of several layers of a limeand gypsum-based plaster (gauging plaster) and only salient elements of the face (e.g. lips, eyes and hairline) and the hair were painted, with a high-quality red ochre and with an unidentified black pigment, respectively. A careful examination of the construction of the head allowed to determine that it probably belonged to an iconic representation of the Buddha, as opposed to a narrative scene.

Keywords. Gandhara, stucco, gauging plaster, polychromy.
Résumé. Cette étude présente les résultats d'une recherche technique et historique sur une importante tête du Gandhara conservée au Victoria and Albert Museum, à Londres. Cette cuvre occupe depuis des années une place éminente dans l'histoire de l'art gandharien en raison de sa grande qualité esthétique. Pourtant, elle n'a guère été étudiée scientifiquement depuis son exposition au musée dans les années 1930. Aux recherches sur les données matérielles, muséales et de conservation-restauration s'est ajoutée une analyse structurelle utilisant des techniques non-invasives hors contact : imagerie, spectroscopie IRTF (Spectrométrie infrarouge par transformée de Fourier), XRF (analyse par fluorescence X), FORS (Spectrométrie par réflexion à l'aide de fibre optique). Le support se compose de plusieurs couches de mortier chaux-plâtre (plâtre de gâchage). Les pigments, appliqués uniquement sur les principaux traits du visage (tels que les lèvres, les yeux) et sur les cheveux, sont respectivement une ocre rouge de grande qualité et un noir non identifié. Un examen attentif de la construction de la tête a permis de déterminer qu'elle appartenait probablement à une représentation iconique du Bouddha, par opposition aux scènes narratives.

Mots-clés. Gandhara, stuc, plâtre de gâchage, polychromie.

\section{Introduction}

The appearance of ancient stone sculpture in the Mediterranean, Central Asia and the India Subcontinent is often associated with pristine, unpainted surfaces, appreciated for their unblemished appearance. This is certainly the case for ancient Greek and Roman sculpture, which has been long praised for its whiteness ${ }^{1}$. However, it is a well-known fact that ancient sculpture was generally painted and the Buddhist sculptures from the Gandharan region are not an exception. While most schist sculpture now appears "elegantly" uniform and grey, stucco sculpture, by nature more porous than schist, often retains traces of their original painted decoration ${ }^{2}$. While the making of ancient Greek and Roman sculptural polychromy has been the subject of intense scholarly studies and fierce debates since at least the late 18 th century ${ }^{3}$, Gandharan sculptural polychromy has received limited attention. Only a handful of technical investigations exist on metal and schist sculpture ${ }^{4}$, and on clay and stucco ${ }^{5}$.

This paper focuses on the history, making and significance of a $c$. 4th-5th century stucco head in the Asian collections of the Victoria and Albert Museum (IM.3-1931) and

Giovanni Verri, Conservation Scientist, The Art Institute of Chicago, Chicago, IL, USA (gverri@artic.edu). Christian Luczanits, Senior Lecturer, Department of History of Art and Archaeology, School of Arts, SOAS, London, UK (cl46@ soas.ac.uk). Victor Borges, Senior Sculpture Conservator, Sculpture Conservation, Victoria and Albert Museum, Cromwell Road, London, UK (v.borges@vam.ac.uk). Nick Barnard, Curator, Asian Department, Victoria and Albert Museum, London, UK (n.barnard@vam.ac.uk). John Clarke, Curator, Asian Department, Victoria and Albert Museum, London, UK (j.clarke@vam.ac.uk). 
identifiable as the Buddha by the presence of lakshanas, or auspicious marks, such as the hair knot, or ushnisha, and the forehead mark, or urna. The presence of the elongated and pierced earlobes is an allusion to the Buddha's former princely status, when he wore heavy pendant earrings (fig. $1 \mathrm{a}$ ). The head still retains traces of red colour on various areas, including the lips, the eyes, the philtrum and hairline. Small remnants of a black pigment can also be seen in the hair and above the upper lip. The materials and techniques used to create the head are studied using scientific techniques and placed within a wider archaeological/art-historical context, to provide further insights into its original appearance, provenance and function.

\section{Stucco: lime, gypsum or clay?}

The term stucco is commonly used to describe a plastic material that, upon setting, hardens to a solid, dense material, which is relatively durable. The plasticity of the material allows it to be modelled and moulded in complex sculptural forms ${ }^{6}$.

Despite its confusing and multiple definitions, and to maintain a continuity in the traditional terminology, in the context of this paper, the term stucco will exclusively refer to lime- $\left(\mathrm{CaCO}_{3}\right)$ or gypsum- $\left(\mathrm{CaSO}_{4}\right)$-based compounds, which are the binding agent and whose properties can be modified by the addition of aggregates, such as sand and straw, and additives, such as organic materials, including gums, proteins, oils, etc. Therefore, earthen-based compounds, in which clays constitute the main binder, with the addition of aggregates and additives, will not be included in the definition of stucco ${ }^{7}$. This terminology is therefore bound to create some level of confusion, as earthen-, lime- and gypsum-based compounds are commonly encountered together in Gandharan stucco sculpture, where an earthen-based core serves as a secondary support for the lime- and gypsum-based stucco; the secondary support, which is connected to a primary support/architecture, can also be made of stone, stone rubble, lime-based stucco, wood and other composite materials ${ }^{8}$.

\section{Methodology}

An iterative and incremental approach was used for this study, which begun with archival research on the physical, curatorial and conservation history of the head. Subsequently, a sequence of non-invasive investigations was undertaken in order to understand the materials and techniques used for the creation of the head. Following visual observations with and without the aid of magnification, ultraviolet and infrared imaging was used to identify areas for point analysis with analytical techniques: $\mathrm{X}$-ray fluorescence spectroscopy (XRF) was undertaken to determine elemental composition, Fourier-transform infrared spectrometry (FTIR) was used to identify organic and inorganic compounds and Fibre optics reflectance spectroscopy
(FORS) was employed to characterise the pigments. 3D photogrammetry was used to study the position of the head with respect to the viewer in different contexts (see the Appendix for the details of the experimental setups).

\section{A stucco head of the Buddha at the V\&A}

\section{Physical history}

IM.3-1931 is an approximately life-size (H. 29 cm; W. 18 cm; D. $19 \mathrm{~cm}$ ) head, now in the collections of the Victoria and Albert Museum, London. The head was acquired in 1931 for the expensive sum of $£ 500$ from Harold Spink (Spink and Sons). Before the head was acquired, culturally significant exchanges took place between the museum curators and the experts in the field at the time. A summary of these conversations will be reported here ${ }^{9}$. From the earliest exchanges between H. Spink and the museum, it appeared clear that the head had attracted considerable attention because of its aesthetic qualities. On 27 June 1931, A. J. D. Campbell, the curator of the Indian Section, writes to Sir Eric Maclagan, the director and secretary of the museum, suggesting the purchase of the head. He describes the head as a "Bodhisattva-head of prince Siddhartha, cast from a mould in lime-composition with traces of tinting. Made at the extreme end of the Graeco-Buddhist period, in the 5th century A.D”. He goes on to add that:

"The Bodhisattva is a supreme work of art and only requires to be seen, for its necessity for the India Museum collection to be apparent. Its condition is practically perfect. There is no piece in the examples of the Graeco-Buddhist period in this museum which approaches it in technique and spiritual beauty, and if purchased, it will be a permanent refutation to those critics who hold that no good thing came out of this school."

On 30 June 1931, Sir Eric Maclagan writes to the Earl of Ilchester for advice, mentioning that he could not reach expert Sir Edward D. Maclagan, the President of the Royal Asiatic Society of Great Britain and Ireland. After stressing that Campbell had praised the significance of the head, he adds that, because of the absence of his cousin E. D. Maclagan, he had showed a:

"photograph [of the head] to [Reginald] Blomfield at the Athenaeum this morning, since he is our principal adviser for sculpture other than Indian. He is enthusiastically in favour of the purchase; indeed he admired the head a great deal more than I had expected that he would! I feel bound to add that Lord Lee, on the other hand, says that it looks like Greta Garbo at her worst."

Ilchester's first response is that the "the photo gave [him] a somewhat lackadaisical impression!”. However, after viewing the object, he writes: "The head appears to me to be the most remarkable, and as I suspected the photograph does not do it justice." Importantly, he also adds that committees of qualified experts should be put in place to advise on acquisitions. 
On 15 July 1931, just approximately two weeks after the head was presented to the museum, the director confirms the purchase, which is received with much enthusiasm by $\mathrm{H}$. Spink the following day.

These exchanges provide an interesting insight into the perception of Asian art in the first part of the 20th century: the need for Campbell to refute the detractors of the art of Greater Gandhara and the comments of Lord Lee, despite the late date, appear to betray a lingering prejudice towards non-Western art.

The head has been on display since its purchase and widely appreciated for its aesthetic qualities. However, despite the fame of the head, which has travelled to a number of international exhibitions over the decades, it has received limited scholarly attention. Based on art-historical comparisons, it has tentatively been assigned to the site of Hadda in Afghanistan ${ }^{10}$, as well as to the monasteries in Taxila, Pakistan, with stylistic influences from Gupta art ${ }^{11}$.

\section{Curatorial and conservation history}

Since its purchase, the head appears to have been on prominent display as an example of Gandharan art. The earliest surviving photograph (1931) - possibly the very one attached to Maclagan's letter - shows the head mounted frontally on a dark, square support, with the length of the neck running parallel to the supporting dowel, which is invisible in the photograph (fig. 1 a; see also another early view in fig. $1 \mathrm{~b})$. The orientation of the dowel gives the head an inclined position with a markedly downward gaze. Figure $1 \mathrm{~b}$ clearly shows burial deposits on and around the right ear. In pre-1988 images, the head appears to be mounted with a similar orientation, but on a lighter base, with plaster connecting the broken section of the neck to the mounting block (fig. 1 c-e).

The record is silent until 1984, when John Larson, Head of Sculpture Conservation, requests for a "cutting of a limestone base block and fitting". Conservator Kate Garland observes that there are "layers of grime covering [the] stucco and concealing [the] polychrome[y]. Also some fine clay concealing pigment - especially around the ears - has been excessively cleaned in the past, removing virtually all pigment". Figure $1 \mathrm{c}$ probably shows the head prior to the cleaning intervention in the 1980s. In this occasion, the surface of the head was "brushed with a dilute $(3-5 \%)$ solution of polyvinyl alcohol (Rhodoviol 11-125, Rhône-Poulenc, France) to consolidate the remaining pigment" and cleaned under the microscope with swabs and de-ionised water. Greasier areas were instead treated with a "50/50 solution acetone/water". In addition, "hot water cotton wool poultices were used on the cheeks and chin, were the grime was particularly stubborn". The fine clay in the hair and ears was softened with water and subsequently thinned to reveal more pigment. The inner layers, visible at the back of the head and the bottom of the neck, were consolidated with Raccanello 55050 - an acrylic silane mixture, and a "dilute PVOH solution brushed on [the] surface to saturate pigmented areas". Figure $1 \mathrm{~d}$-f probably shows the head after the cleaning treatment. 


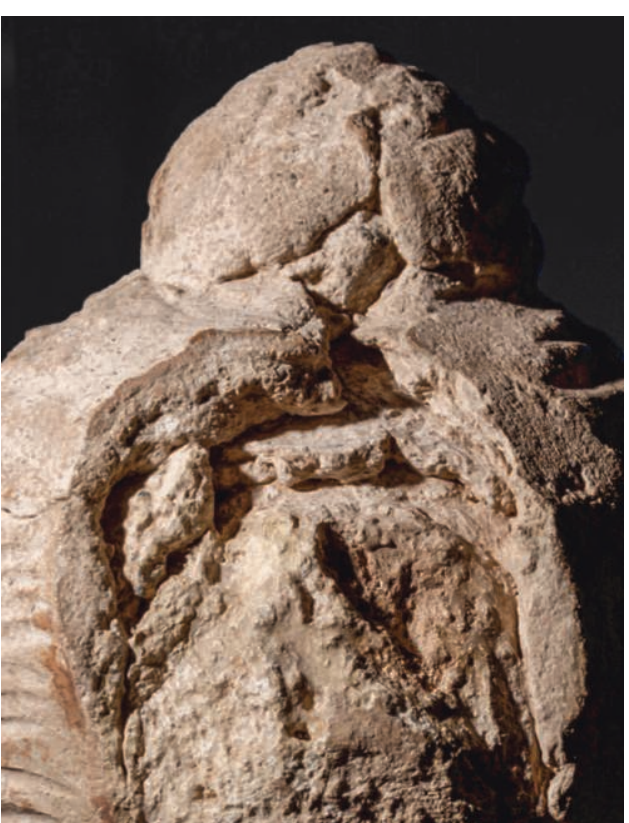

Fig. 3. Detail of the rear of the head, showing the inner stucco layers, irregularly applied on top of one another. These layers are composed of a lime-based stucco with some gypsum, large mineral aggregates (schist(?)) and vegetable fibres to counteract

shrinkage upon setting. A finer, smoother layer of a similar composition, but with smaller aggregates, is applied atop the course layers and modelled while still fresh, as can be observed by the wide incision at the bottom left of the image. (c) G. Verri. Courtesy of Victoria and Albert Museum.

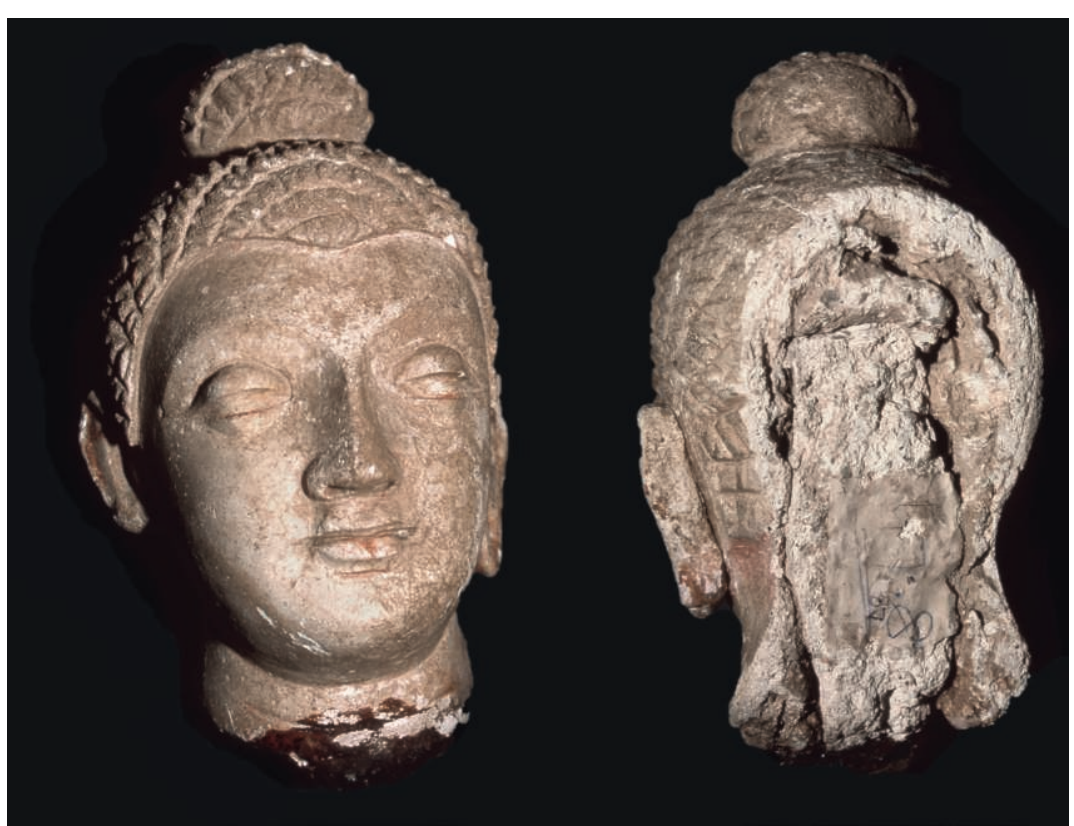

Fig. 4. Head of the Buddha, Lucknow State Museum, no 47,87. Front view (left) and rear view (right), showing the layers of stucco with aggregates forming the supporting structure of the head. (C) C. Luczanits.
In 1988, conservator R.O.G. Cook removed a copper dowel from the neck by chiselling out the plaster, which held it in place. In the conservation record, a photograph of the head shows the interior of the stucco (fig. $1 \mathrm{f}$ ). As this image probably corresponds to the 1988 intervention, when the copper dowel was removed, it may allow us to also date the similar photographs in figure $1 \mathrm{~d}$ and e to the same year. With an Ancaster limestone mount, which was inserted in 1988 and currently in place, the head is presented with a slightly different inclination, as the dowel is now roughly parallel to the main axis of the head, rather than the neck ${ }^{12}$. The head was assessed by conservator Victor Borges in the Sculpture Conservation Department prior to its installation in The Robert H. N. Ho Family Foundation Galleries of Buddhist Art in 2017. It was found to be structurally stable and no treatment was deemed necessary, in accordance to the principles of minimal intervention ${ }^{13}$; such principles were not always abided by during periods of more interventive and experimental approaches, as in the 1970s or 1980s. The only modification was the new display plinth which allows the head to be displayed on an angle much closer to the original position of the head.

\section{Results and discussion}

Core and coarse stucco layers

Figure 2 presents four views of the head. A detail of the back view shows that it is composed of several superimposed layers of stucco (fig. 3). Varma indicates that this type of sculpture normally comprises a core (wood, stone, rubble, earthen plasters or stucco, etc.), around which layers of earthen plasters and/or stucco are applied to build up the shape of the figure $^{14}$. The only photograph of the inner parts of the head dates to 1988 and does not show remains of any material other than stucco (fig. $1 \mathrm{f}$ ). Similarly, the X-ray radiograph of the head (not shown here) shows a fairly uniform composition throughout the thickness of the head. At the centre of the head, the radiograph reveals the modern stainless steel dowel and, around and above it, a darker area, corresponding to the less-dense polyester resin, which keeps the dowel in place. While the now-hollow internal part of the head might have originally housed a wooden or stone core, there is no clear evidence for its original presence (see fig. 4 for another example of this kind of construction). The interfaces between layers are too thin to be clearly distinguished in the radiograph. However, at least four layers of uneven coarse stucco, 


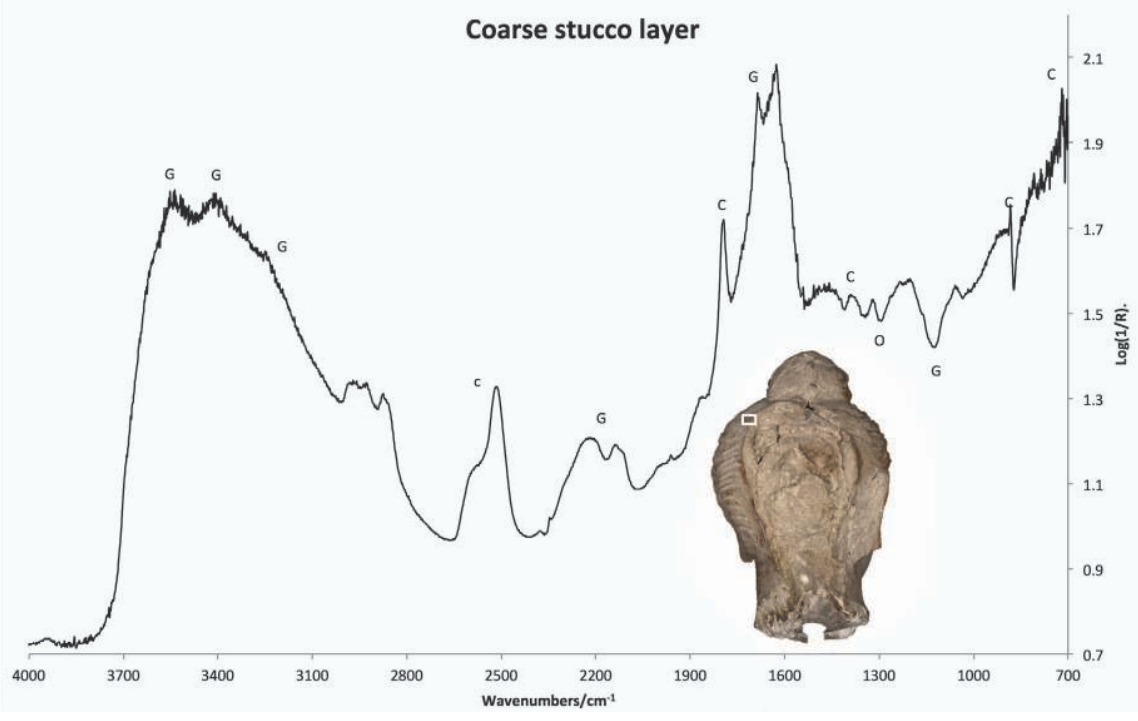

Fig. 5. FTIR spectrum of one of the course layers of stucco. All course stucco layers have a very similar composition. "C" indicated the vibrational modes of calcite, "G" of gypsum and "O" of calcium oxalates (whewellite/weddellite). (c) G. Verri.

approximately $0.5-1 \mathrm{~cm}$ thick, are visible at the rear of the sculpture (fig. 3). More may be present, but remain invisible to the naked eye and did not appear clearly in the X-ray radiograph. FTIR investigations (fig. 5) revealed that the binding matrix of these four layers of stucco is very similar and composed of calcium carbonate ${ }^{15}$ with some calcium sulphate ${ }^{16}$. Small amounts of calcium oxalate $\left(\mathrm{CaC}_{2} \mathrm{O}_{4}\right)$, in their hydrated forms (whewhellite $\left(\mathrm{CaC}_{2} \mathrm{O}_{4} \cdot \mathrm{H}_{2} \mathrm{O}\right)$ or weddellite $\left.\left(\mathrm{CaC}_{2} \mathrm{O}_{4} \cdot 2 \mathrm{H}_{2} \mathrm{O}\right)\right)$, were also observed ${ }^{17}$.

While gypsum may be present as an impurity, it could also be derived by a partial and superficial sulphation of the lime matrix due to historic environmental pollution ${ }^{18}$. However, another, more likely explanation is that calcium sulphate hemihydrate $\left(\mathrm{CaSO}_{4} 1 / 2 \mathrm{H}_{2} \mathrm{O}\right)$, also known as Plaster of Paris, was intentionally added to change the working properties of the stucco. The addition of calcium sulphate hemihydrate to lime putty accelerates the drying time of stucco and also influences its performance characteristics, by reducing its shrinkage; known as gauging plasters and widely attested in Italy in the 17th and 18th centuries, these compounds allow for a more controlled and rapid operation, when constructing the various layers, which would otherwise require longer setting time in the case of pure calcium hydroxide, or slaked lime $\left(\mathrm{Ca}(\mathrm{OH})_{2}\right)^{19}$. In Antiquity, this type of mixture (gypsum and calcite) was observed in Parthian stucco by Simpson in $2012^{20}$. However, already

Fig. $6 a$-b. a. Coarse stucco (right) and finishing stucco (left) layers at the rear of the ushnisha. The finishing plaster has a more homogeneous distribution of angular aggregates, which might have been deliberately crushed and added to the lime and gypsum matrix to create a finer surface, in which to model the details of the neck, face and hair with greater precision; b. Detail of the coarse plasters at the neck level, showing the course schist-like aggregates, other small coloured rocks of different dimensions and the remnants of coarsely chopped fibres (centre). (C) G. Verri/V. Borges. Courtesy of Victoria and Albert Museum. in 1996, Middleton ${ }^{21}$ noticed the presence of this mixture in Gandharan stucco in an unspecified number of examples from the Gandharan collections at the British Museum, but does not discuss its use in detail. Similarly, Varma $^{22}$ reports Barthoux's own observations of lime/gypsum stucco from Hadda $^{23}$.

The presence of oxalates could be attributed to the degradation product of an organic material, e.g. an additive, such as a gum, protein or oil ${ }^{24}$, added to the stucco mixture to improve its working properties and performance characteristics upon setting. However, it could also be the result of the degradation of a more modern consolidant, such as those applied to consolidate powdery paint layers. In addition, the $\operatorname{method}(\mathrm{s})$ of formation of oxalates remains poorly understood and microbiological sources are also a possibility ${ }^{25}$. Thin-section analysis may shed more light on the nature, origin and distribution of the calcium oxalates. Irregular and generally round in shape (max. 0.3-0.5 cm long), schist(?), small rocks and vegetable fibres ${ }^{26}$ are homogeneously dispersed in the matrix (fig. $6 \mathrm{a}$ and b). The

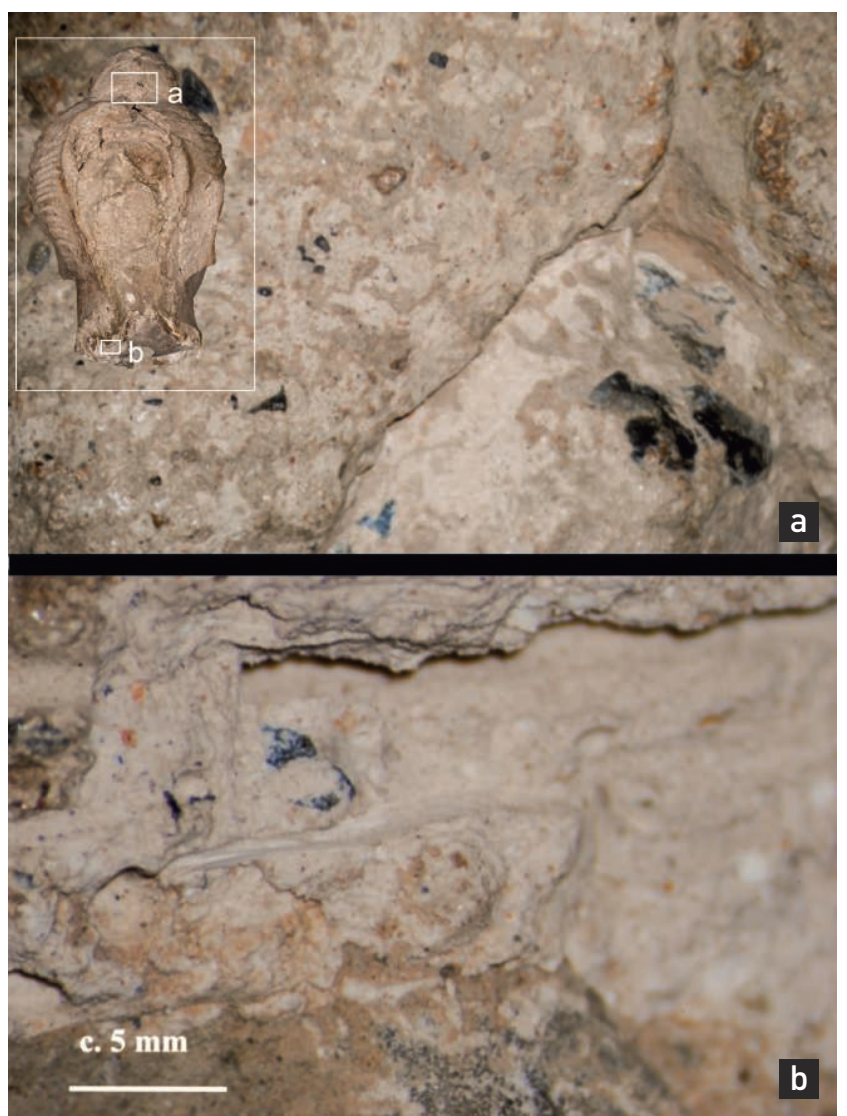



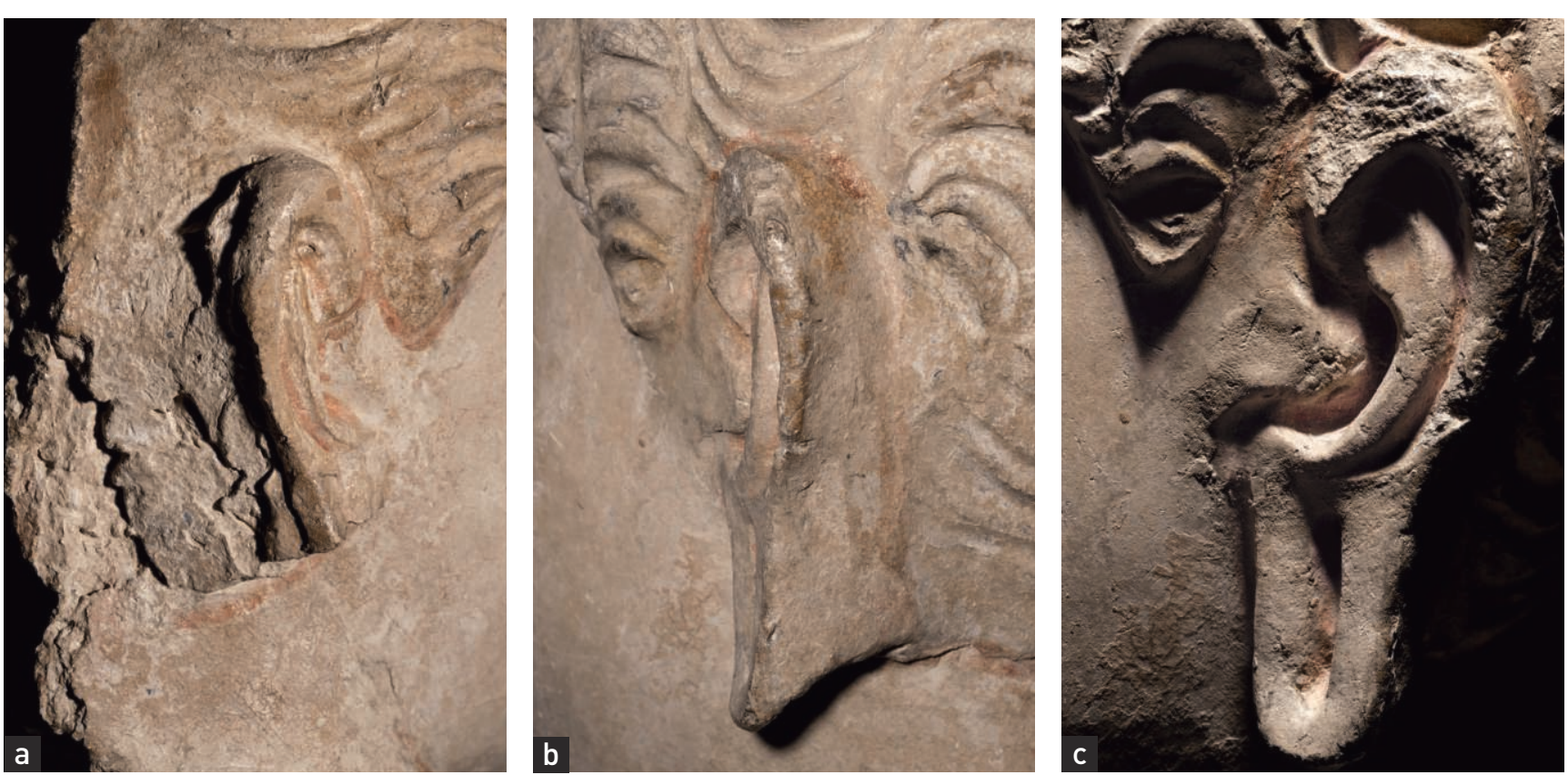

Fig. 7 a-c. a. Right ear; b. Left ear. Stucco was amassed at the back of the ears to support them. The right ear, which is very close to wall, was not finished at the back, while the left ear was highly finished, as it was more visible. In addition, the stucco supporting the lobe forms an angle with the head. This may suggest that the head was seen from below, as the angled support would have given the impression of a freely dangling elongated earlobe; c. The left ear in raking light, where the fingerprints of the artist can be seen on the tragus. (C) G. Verri. Courtesy of Victoria and Albert Museum.

function of the aggregates and fibres is to counteract the shrinkage of calcium hydroxide upon setting; the round shape of the rocky aggregates seems to indicate that they were not all intentionally crushed for the purpose of making the sculpture. Fibres, which are now white in colour - perhaps bleached by the high alkalinity of the binding medium - also appear to be irregular in shape and length. In some instances, the fibres themselves can be seen under magnification and, when gently touched, they are found to still retain some elasticity. However, in many other instances, the fibres have entirely disappeared, leaving an impression of their striated shape in the stucco. It remains unclear if the missing fibres were lost because of mechanical action or have decayed over time.

\section{Finishing layer and skin tones}

Atop the coarser stucco layer, a finishing layer $(c .0 .5-0.8 \mathrm{~cm})$ is applied. The matrix of the finishing layer has a very similar composition to that of the coarse layers (lime with some gypsum), but the aggregates and fibres appear finer and more homogeneous in both size and distribution. The overall coloration of the aggregates is similar to that of the coarse layers, but the shape of the aggregates is generally more angular (fig. 6 a). This observation may indicate that they were deliberately crushed, sieved and added to the finishing stucco layer, to provide the artist with a finer surface, on which to accurately model the details of the hair, face, ears and neck. Another possible explanation is that the stucco mixture itself was further ground or sieved and used for the uppermost layer. This lime- and gypsum-based finishing layer was worked, while still wet, with tools and fingers; the incisions used to form the hair are particularly clear at the back, where they have not been finished to the same level of accuracy as the front (see for example the bottom-right of figure 3, where rough incisions with a rounded tool form the wavy strands of hair). However, rather deep incisions with accumulated stucco at the edges, which clearly indicate that the head was modelled while the stucco was still fresh, can also be seen in many locations on the face, including the eyes and the nose. It has been reported ${ }^{27}$ that, while the hair was indeed clearly modelled by hand, the face was created with the aid of a mould and subsequently finished by hand. While this in principle not impossible, in accordance with Varma's observations ${ }^{28}$, it appears more likely that the head was entirely modelled freehand, given the highly three-dimensional nature of the face and the presence of incisions that could have only been made on fresh stucco.

The ears (fig. $7 \mathrm{a}-\mathrm{c}$ ), which also appear to have been made of the finishing stucco, were created by amassing layers of stucco and then finished to the same level of quality at the front. The back of the right ear, however, which was very close to the wall and therefore difficult to model and not easily visible, is roughly finished with the supporting layers clearly observable (fig. 7 a). By contrast, the back of the left ear, which was considerably more exposed, is highly finished and the supporting stucco is modelled to closely follow the shape of the ear (see also below for further considerations on the original orientation of the head in situ) (fig. 7 b-c). A very similar head of a Buddha in the St Louis Art Museum 
(43:1931, intriguingly acquired in the same year as IM.3-1931 and sharing remarkably similar stylistic details, such as the hair and facial features) shows a nearly identical orientation and treatment of the ears (fig. 8). The different level of finish of the ears is also possibly an additional indication that the head was modelled in situ, rather than ex situ and subsequently mounted on the body by means of a dowel. The back of the right ear might have not been fully finished because of the limited space between the wall and the ear, rather than exclusively because it was not easily visible.

On the skin of the face only, an even finer layer appears to have been applied (fig. 9). This layer, approximately $1 \mathrm{~mm}$ thick, is however not visible in all areas. This may indicate that the fine layer was applied over the finishing layer when the latter was not fully set, so the two have merged "seamlessly". For example, this layer is clearly visible in the neck area, but not along the hair-

line. It also possible that the application of the fine layer was performed in different stages, making the modelling progress not necessarily linear or straightforward to interpret. This layer is composed of mostly gypsum, lime and very small aggregates (submillimetric). The FTIR spectrum (fig. 10) shows the $\mathrm{OH}^{-}$bending (peaks at $c .1626 \mathrm{~cm}^{-1}$ and $1685 \mathrm{~cm}^{-1}$ ) and stretching (peaks at c. $3404 \mathrm{~cm}^{-1}$ and $3547 \mathrm{~cm}^{-1}$ ) of
Fig. $9 a-b$. a. The skin tones are made of a thin layer of a gypsum-rich lime-based stucco layer, approximately $1 \mathrm{~mm}$ thick. In some areas, as in the neck, this layer is quite clearly visible, while in some other areas, as along the hairline, it appears to have blended seamlessly into the finishing stucco layer. This may suggest that stucco layers were not fully set when new layers were applied. Linear "scars", possibly the impressions left by now-lost fibres, are also evident on the cheek; b. Detail of skin tones below the left eye, showing the presence of various aggregates, including hematite. (c) G. Verri. Courtesy of Victoria and Albert Museum.
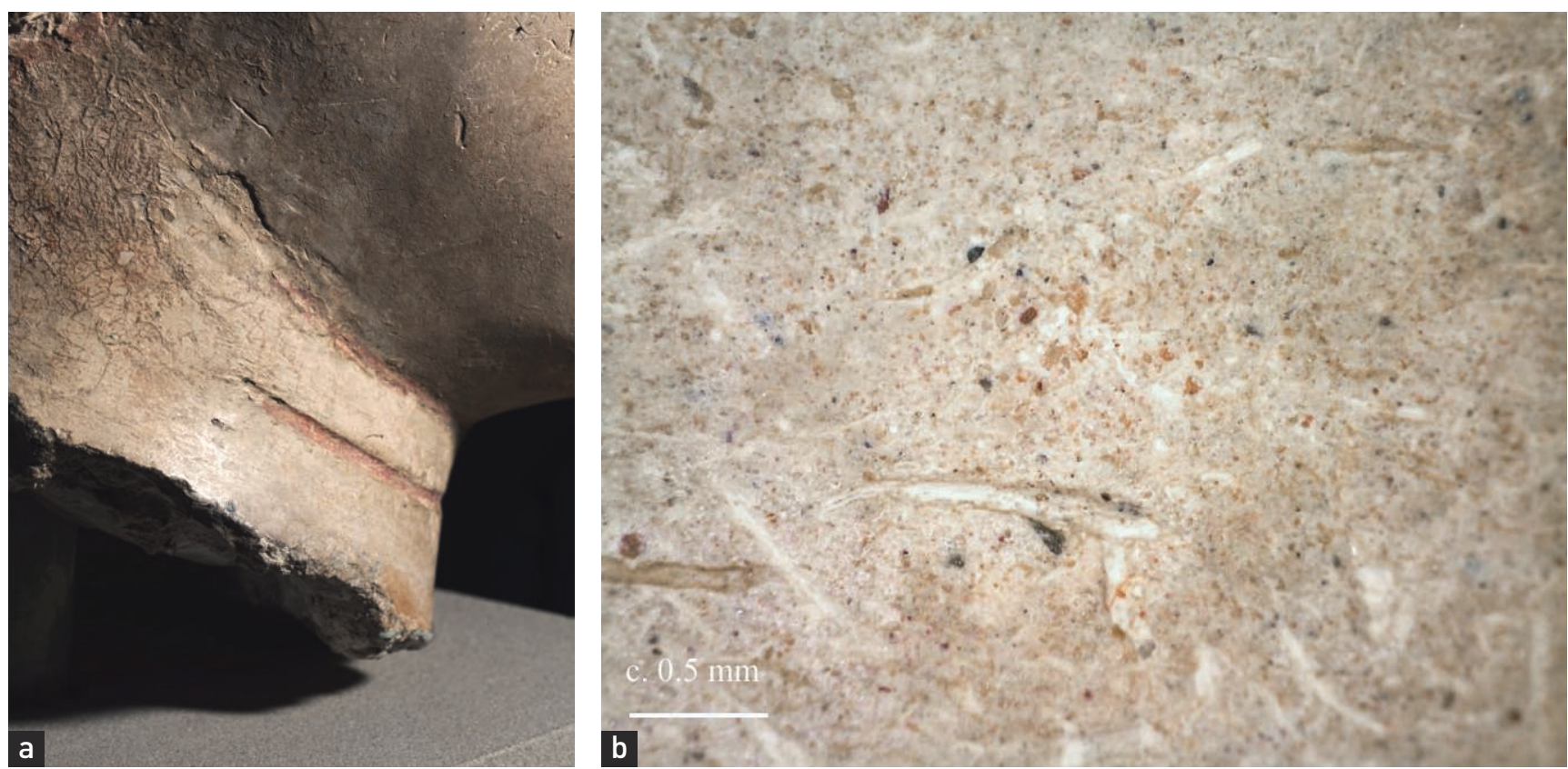


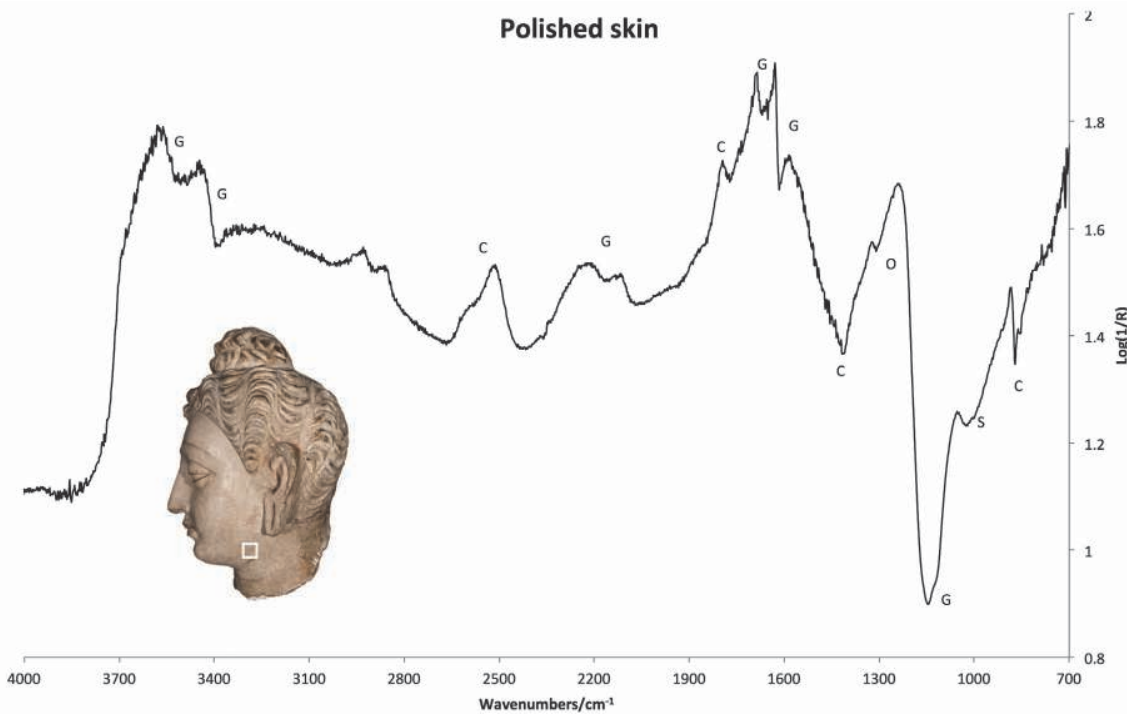

Fig. 10. FTIR spectrum of the polished skin. The surface is highly polished, so that derivative phenomena prevail for $\mathrm{OH}^{-}$bending and stretching modes for gypsum. "C" indicated the vibrational modes of calcite, "G" of gypsum, "O" of calcium oxalates (whewellite/weddellite) and "S" the possible presence of a silicate, potentially caused by the fine aggregates. () G. Verri. Courtesy of Victoria and Albert Museum.

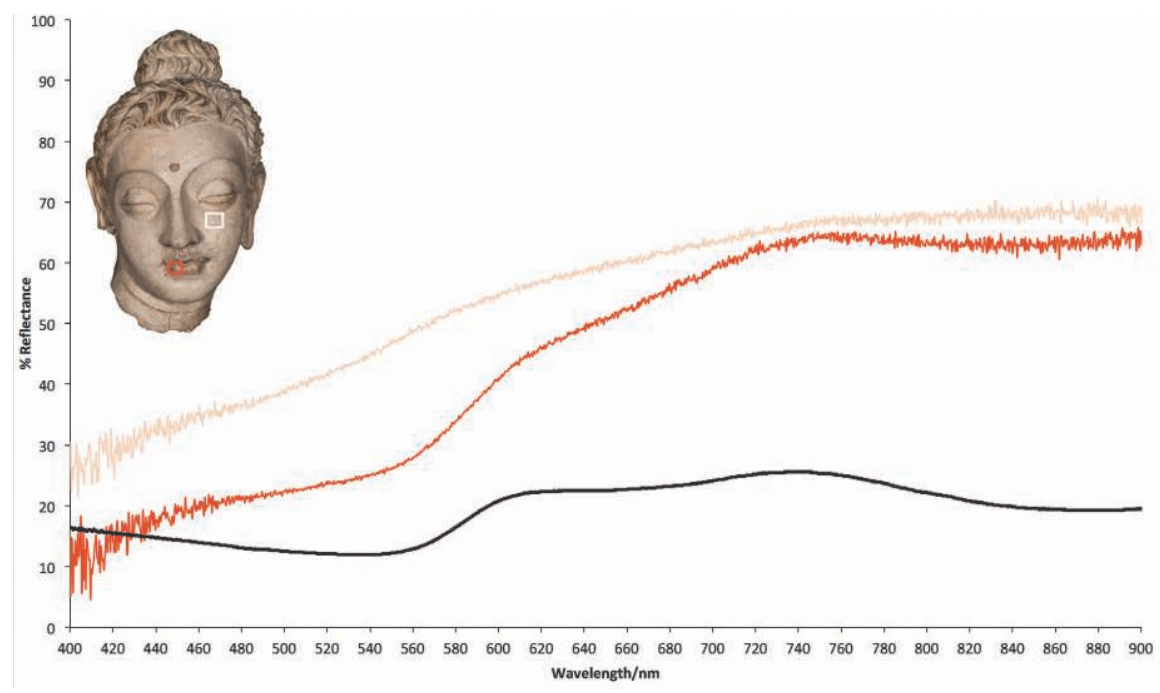

Fig. 11. Reflectance spectra of the skin tones (light red), the lips (dark red) and a hematite reference standard (black). Hematite, in the form of red ochre, is found in the skin tones in small quantities, while the red used for the lips and other details is fairly pure.

(c) G. Verri. Courtesy of Victoria and Albert Museum.

gypsum in a pronounced derivative mode ${ }^{29}$. A considerable number of red and yellow, sub-millimetric aggregates are also present in this layer. As already observed by Middleton ${ }^{30}$, red aggregates are present in polished layers to impart the layer a pale buff, flesh tone. As already speculated by Middleton ${ }^{31}$ and Tarzi ${ }^{32}$, FORS measurements confirmed the use of a hematite $\left(\alpha-\mathrm{Fe}_{2} \mathrm{O}_{3}\right)$-rich compound, probably a red ochre (fig. 11, light red line), thanks to the inflection point at $c$. $580 \mathrm{~nm}$ and apparent absorbance maximum at $c .875 \mathrm{~nm}^{33}$. These features are barely visible, as the red pigment is not abundant. Small recessed areas, reminiscent of now-lost fibres are scattered on the skin of the face, suggesting that fibres were also originally mixed in the finer layer or that the finishing layer below was partially exposed during the polishing process. The skin of the face is now polished to a sheen, but more recessed areas still retain the impressions of fingerprints, such as on the sides of the nose. While the impact of modern consolidation may have contributed to the polished appearance of the skin tones, when the head is observed with a strong raking light, the cheeks appear not to be smooth, but characterised by "facets", possibly the result of the pressure imparted by a metal (?) tool (fig. 9 a). When semi-set, that is when the surface of the stucco is beginning to harden, lime-based plasters can be polished to high levels of brilliance, as already observed by Vitruvius in his discussion of Roman plasters ${ }^{34}$. In addition, the derivative mode of the $\mathrm{OH}$ stretchings and bendings of gypsum, as discussed above, also indicates that the surface is highly reflective ${ }^{35}$.

\section{Polychromy}

Red pigment is still clearly visible on the lips, philtrum, nose, lower eyelid, urna, ears, chin, neck folds and hairline and a black colour is also present above the lips and in the hair. The FORS spectrum of the red areas (fig. 11, dark red line) revealed the presence of hematite as the main chromophore, again suggesting the use of a red ochre; this result was confirmed by the presence of iron in the XRF spectrum (not reported here). With the exception of the lips, where the colour appears to have been applied thinly on the whole lips with an additional strengthening line on the upper and lower edges of the lips, as well as the in the sinuous fold separating the lips, the paint layers have been applied as single lines. This type of paint application is quite common in Gandharan stucco (see, for example, the bodhisattva head at the British Museum, BM 1962, 0421.2 and the Buddha head in the Saint Louis Art Museum, fig. 8). The black pigment could not be identified with the available instrumentation. It remains unclear if the black colour above the lips is the remnant of a painted moustache. However, its distribution is not consistent and the infrared image did not reveal 
Fig. 12. UV-reflected image. Brighter areas, probably corresponding to now-lost painted caruncles, can be seen in the corners of both eyes. ( $)$ G. Verri. Courtesy of Victoria and Albert Museum.

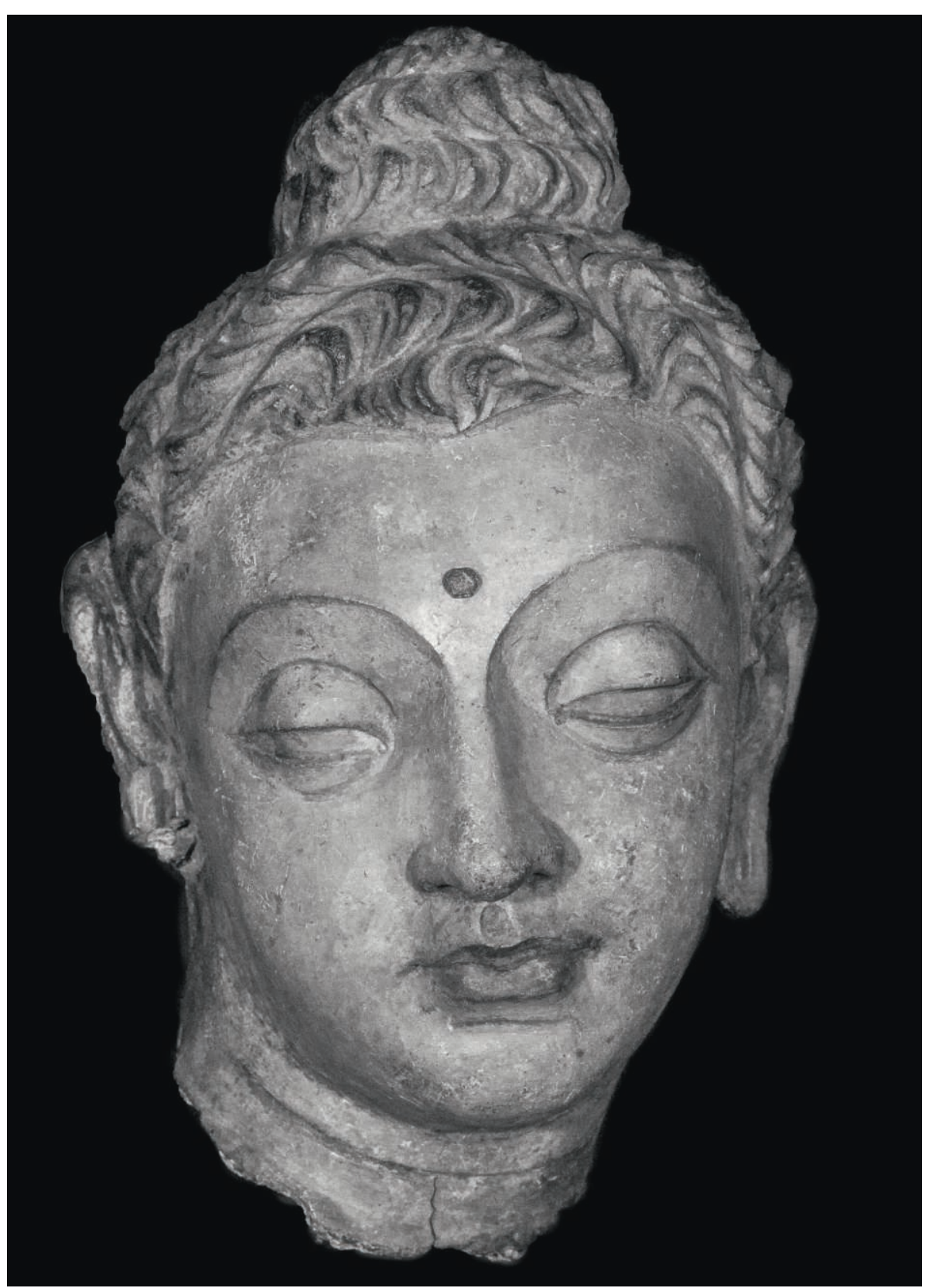

145 any further indication on the presence of moustaches. No clear traces of pigment could be seen in the pupils, but the UV-reflected image shows dark areas within the eyeballs. UV radiation is normally strongly absorbed by organic compounds, such as binders, which appear darker in a UV-reflected image. While these dark areas are reminiscent of irises (fig. 12), their shape does not compare well with to the way in which irises are normally represented in Gandharan art (e.g. BM 1962, 0421.2), as they are rather large and extending from the upper to the lower eyelid. Therefore, it is possible that the brighter areas in the corner of the eyes are in fact the remnants of painted caruncles, which give the false impression of large irises.
In many areas, including the skin tones by and below the ears (see, for example, fig. 9 a), a fine buff, silty layer was initially thought to be surviving paint representing a naturalistic skin colour, as in the case of the Mes Aynak examples ${ }^{36}$. However, upon closer examination under magnification, it appears that this layer is more likely to be burial accretion, partially removed during past cleaning interventions. The characteristic craquelure of this layer, which is also found above the red paint layers, is reminiscent of silica-rich soils that have undergone drying and wetting cycle(s). The presence of silicates was confirmed by the $\mathrm{Si}-\mathrm{O}$ antisymmetric stretching, in reststrahlen mode, around $1000 \mathrm{~cm}^{-1}$ in the FTIR spectrum of the area below the left ear (not reported here). 

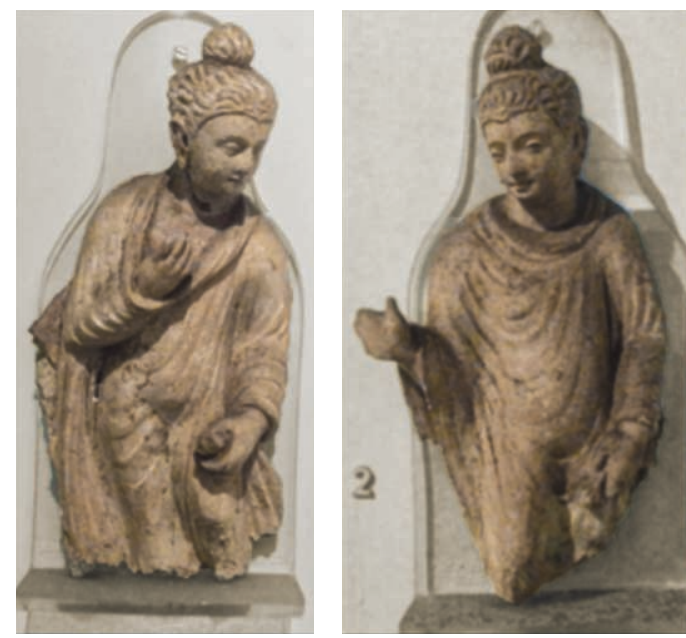

Fig. 13. Stucco Buddhas in the National Museum, New Delhi, India. @ G. Verri.

\section{The orientation of the head}

The rear of the head clearly indicates that the sculpture was not positioned frontally, but in a pronounced three-quarter view. At the back of the sculpture, the portion of the finishing plaster that was in contact with the primary support is in fact positioned considerably closer to the right ear than the left (fig. 2). The exact position of the vertical axis of the head with respect to the normal of the supporting wall is more difficult to determine; two likely orientations might have run along the length of the neck or the length of the head either of which could have been positioned roughly perpendicularly to the ground. These two orientations summarily correspond to the early mounting (fig. $1 \mathrm{a}$ and c) and the current (fig. 2 a); the first option sees the head pronouncedly tilted to the right, while latter sees the neck at an angle with the rest of the body. However, if it is assumed that the main axis of the head (or the neck) was nonetheless approximately positioned in parallel to the plane of the supporting wall, figure 2 c suggests that another structure, probably an inclined halo, was protruding towards the top of the head (see the dotted lines, indicating the different orientations of the interface between the finishing plaster and the support).

While inclined halos are not a common feature of Gandharan art, their use might be understood when considering the height at which the sculpture was intended to be observed (see below). In her comprehensive study of the head, Errington ${ }^{37}$ suggested that the head could have been part of a group of seated Buddhas and mentions Mohra Moradu as an example ${ }^{38}$, which shows a seated Buddha whose face is just slightly turned to the left. Another possible explanation will be examined here, as the inclination of the head and the pronounced three-quarters position are also commonly found in standing figures. Additionally, if a late dating (4th-5th century), as suggested by John Guy ${ }^{39}$ and others, is accepted, it is more likely that a standing figure in a three-quarters view would have been part of set of flanking Buddhas, rather than a character in a narrative scene, as also suggested by Guy ${ }^{40}$; moreover, large-scale stucco composition of narrative scenes are in fact presently unknown in Gandharan art. By contrast, progressive elements of Mahayana thought become more and more popular in late Gandhara, as argued by Rhi in his essay on aspects of Mahayana in Gandharan Buddhism ${ }^{41}$, as well as earlier by Lamotte ${ }^{42}$ and
Fig. $14 a$-b. a. (top) plinth of southern façade of Stupa K, 1 at Tapa-i-Kafariha, Hadda (Barthoux, 2001, p. 121, fig. 102), showing a sequence of life-size Buddhas with inclined heads; b. Northern face of the main stupa at Jaulian near the city of Taxila (Marshall, 1951, pl. 106), showing largescale Buddhas between pilasters, similar to (a). 


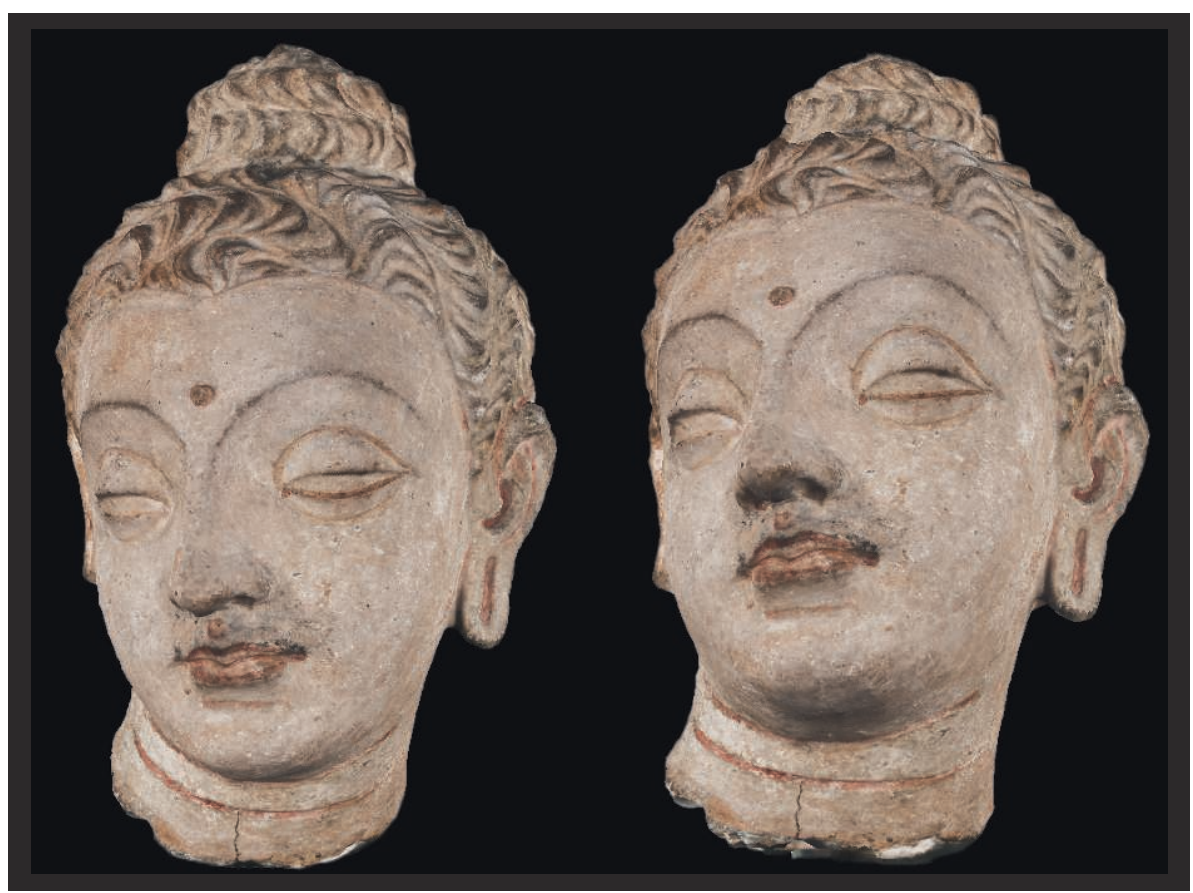

Fig. 15. 3D photogrammetric reconstruction showing the head from two possible viewpoints. (C) G. Verri. Courtesy of Victoria and Albert Museum.

Bechert ${ }^{43}$. Figure 13 shows an example of two symmetrical, standing Buddha figures presented in a three-quarter view from the National Museum in New Delhi. In this example, the left figure is visibly bent at the waist, giving the head a considerable twist, while the figure on the right, which is more similar to IM.3-1931, is inclined forward and to the right. Another example can be found in the now-lost Buddha triad from the Asian Art Museum, Collection of South, Southeast and Central Asian Art, Berlin ${ }^{44}$. Here the two Buddhas flanking the central Buddha stand with heads bent and in different postures. Therefore, given the wide range of possible positions of such types of figures, it is impossible to unequivocally identify the original orientation of IM.3-1931.

While representations such as the triad of Buddhas described above appear to be a very convincing interpretation, the head may also have belonged to other types of iconic depictions, such as a sequence of Buddhas. An example of this kind of representation can be seen on the plinth of southern façade of Stupa K, 1 at Tapa-i-Kafariha, Hadda (fig. $14 \mathrm{a})^{45}$, or on the walls of the northern face of the main stupa at Jaulian near the city of Taxila (fig. 14 b) ${ }^{46}$. All the Buddhas in Tapa-i-Kafariha have an identical posture, including a tilted head, which is reminiscent of the position of IM.3-1931 and the Buddha head in the St Louis Art Museum (fig. 8); judging from the scale provided by Barthoux for the plinth of the stupa, the standing Buddhas have similar dimensions to IM.3-1931. The stucco figures at Jaulian may give a sense of the overall appearance of such group of figures in their original context. A well-preserved, although smaller than life-size, example is on display at the Musée Guimet (MG 17320), where the three Buddhas from the monastery of Bāgh-Gaï B56, Hadda, are positioned between pillars and show a very slight inclination of the head. However, independently of the original group to which IM.3-1931 belonged, it was probably positioned on a plinth and therefore observed from underneath, as in the examples from Taxila, where many of the shrines were elevated from the ground level. This speculation implies that the ancient viewer would have had a different perspective to what can be appreciated today within a museum context, where the visitor can observe the head from a privileged viewpoint at close quarters. By changing the viewing point, the expression of the head changes considerably, from meditative and pensive to assertive and powerful (fig. 15). The elevated position with respect to the viewer is also in line with the level of finish of the head; as mentioned above, from the front the right ear would have been barely visible - hence its rough finish at the back, while the supporting stucco behind the lobe of left ear was highly finished and modelled at a sharp angle - the stucco support is very thin at the bottom end of the lobe and thicker at the upper end (fig. 7 b), so that it would have not been visible when observed from below, leaving the viewer with an impression of a freely dangling elongated earlobe. 


\section{Conclusions}

The manufacturing technique employed to create the head of the Buddha at the V\&A Museum is in line with previous studies, which noted in some instances the presence of gypsum in a lime-based stucco substrate. This may indicate the intentional use of gauged plasters (lime and gypsum), which can be used to modify working properties and performance characteristics of stucco by, for example, accelerating the setting time. It also confirmed that only some elements (e.g. eyes, mouth and hairline) of the face were highlighted using paint containing a high-quality red ochre. No evidence for now-missing paint layers (e.g. skin tones) were observed. The detailed observation and interpretation of the way in which the head was attached to its primary support, likely a wall, and the level of finish of its components - especially the ears - allowed to speculate that this head might have belonged to an iconic representation of the Buddha, such as a triad, as opposed to a narrative scene.

\section{Acknowledgments}

The authors are grateful to Paul Robins for the X-ray imaging, to the Photographic Studio and the Sculpture Conservation Studio at the Victoria and Albert Museum for their support during the analysis.

\section{Experimental Appendix}

\section{Imaging}

Visible images were acquired using a Nikon D800 camera equipped with two Yongnuo YN-560 flashes and $35 \mathrm{~mm}, 50 \mathrm{~mm}$ and $85 \mathrm{~mm}$ macro Nikkor lenses. Macro-images were captured using a Wild Heerbrugg microscope and a FC-L-OC1 Dino-lite USB microscope. 3D Photogrammetry was undertaken using Agisoft Photoscan and Meshlab software. Multispectral imaging was acquired following the procedures and equipment described in Verri, Saunders, 2014.

\section{$X R F$}

XRF measurements were undertaken using an ELIO spectro-

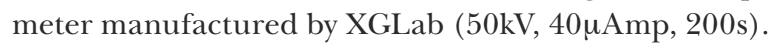

\section{FTIR}

FTIR spectra in the $600-4000 \mathrm{~cm}^{-1}$ range were acquired using a 4300 Handheld FTIR manufactured by Agilent (100 scans, $4 \mathrm{~cm}^{-1}$ resolution).

\section{FORS}

Reflectance spectra in the $300-1000 \mathrm{~nm}$ range were acquired using an Ocean Optics USB2000+ spectrometer and a HL2000 radiation source (100 scans, $0.1 \mathrm{~ms}$ integration time).
Notes

1. Østergaard, 2008, p. 40.

2. Massoudi, 2011

3. Winckelmann, 1764, p. 215; Abbe, 2015.

4. Reedy, 1997; Talarico et al., 2015.

5. Tarzi, 1986; Varma, 1987; Middleton, Gill, 1996; Blänsdorf et al., 2009 and recently Pannuzi et al., 2019.

6. Grove, 2008, p. 635-640.

7. Varma, 1987, p. 13-19.

8. Varma, 1987, p. 58-75

9. V\&A, 1931.

10. See for example Czuma, 1985, p. 215 and Bussagli, 1996, p. 401.

11. See for example Errington, Cribb, 1992, p. 210-211 and Guy, 2007, p. 132.
12. V\&A, 2017.

13. Burra, 2013, Art. 3.1

14. Varma, 1987, p. $63-75$.

15. Weir, Lippincott, 1961, p. 175; Miliani et al., 2012, p. 296-298, 301 and Griffith, De Haseth, 2007, p. 277-279, 349352.

16. Rosi et al., 2010, p. 959-960.

17. Monico et al., 2013, p. 274.

18. Torraca, 2009 , p. $87-88$

19. Torraca, 2009, p. 49; Grove, 2008 ,

p. 636; Montana, Ronca, 2002, p. 144.

20. Simpson et al., 2012, p. 212.

21. Middleton, Gill, 1996, p. 364

22. Varma, 1987, p. 88.

23. See also Pannuzi et al., 2019, p. 65

24. See Bonaduce et al., 2019, p. 87.

25. Monico et al., 2013, p. 270-271.
26. Vegetable fibres (few mm wide and of various lengths), distinguishable by their characteristic striated and structured shape, could not be analysed during this noninvasive investigation.

27. Errington, Cribb, 1992, p. 210-211; Guy, 2007, p. 132

28. Varma, 1987, p. 96.

29. Infrared radiation induces molecular vibrations (e.g. stretching and bending) in which parts of the molecule are harmonically displaced (e.g. stretched or bent) from their equilibrium position (Griffith, De Haseth, 2007, p. 3). Such vibrations are visible in a spectrum as peaks and aid in the identification of the molecule under investigation.

30. Middleton, Gill, 1996, p. 7. 
31. Middleton, Gill, 1996, p. 367.

32. Tarzi, 1986 , p. $84-85$.

33. Aceto et al., 2014, p. 1891-1892.

34. Vitruvius, 1914, p. 207.

35. Miliani et al., 2012, p. 296.

36. See for instance the head of the Buddha in NMA (2012: 45), where traces of a pinkish skin tones can be seen on the cheeks; in the same exhibition catalogue, several other earthen-based Buddha heads still retain considerable amounts of the original skin tones.

37. Errington, Cribb, 1992, p. 210-211.

38. Marshall, 1951, pl. 97(b).

39. Guy, 2007, p. 132.

40. Guy, 2007, p. 132.

41. Rhi, 2006, p. 175-176.

42. Lamotte, 1970 , xiv-Xxvi.

43. Bechert, 1973, p. 11-14.

44. http://dsr.nii.ac.jp/toyobunko/

LFB-2/V-1/page/0051.html.en

45. Barthoux, 1930, p. 121, fig. 102.

46. Marshall, 1951, pl. 106.

\section{Bibliography}

Abbe M., 2015, "The Polychromy of Roman Sculpture", in E. Gazda and E. Friedland (eds.), The Oxford Handbook to Roman Sculpture, Oxford, p. 173-188.

Aceto M., Agostino A., Fenoglio G., Idone A., Gulmini M., Picollo M., Ricciardi P., Delaney J. K., 2014, "Characterisation of colourants on illuminated manuscripts by portable fibre optic UV-visible-NIR reflectance spectrophotometry", Analytical Methods, 6, p. 1488-1500.

Barthoux J. J., 1930, Les Fouilles de Hadda, vol. I and III, Mémoires de la Délégation archéologique française en Afghanistan, Éditions d'Art and d'Histoire.

Bechert H., 1973, "Notes on the formation of Buddhist sects and the origins of Mahayana", in German scholars in India, vol. 1, Cultural Department of the Embassy of the Federal Republic of Germany, p. 6-18.

Blänsdorf C., Pfeffer S., Melzl E., 2009, "The polychromy of the giant Buddha Statues in Bamiyan", in M. Petzet (ed.), The Giant Buddhas of Bamiyan: Safeguarding the remains, ICOMOS, Berlin, p. 237-264.

Bonaduce I., Lluveras Tenorio A., Andreotti A., Orsini S., Colombini M. P., Dilillo M., McDonnell L. A., 2019, "The characterisation of paint binders in the polychromiesand gildings of the Gandharan artworks", in S. Pannuzi, L. M. Olivieri (eds.), Restauro Archeologico, vol. 27, issue 1.

Burra, 2013, Australia ICOMOS 2013, charter for places of cultural significance, The Burra Charter.

Bussagli M., 1996, L'art du Gandhara, coll. Le Livre de Poche, Hachette.

Czuma S., 1985, Kushan sculpture: images from early India, Cleveland Museum of Art in cooperation with Indiana University Press.
Errington E., Cribb J., 1992, The crossroads of Asia: transformation in image and symbol, Ancient India and Iran Trust, Cambridge.

Griffith P., De Haseth, J. A., 2007, Fourier transform infrared spectrometry, $2^{\text {nd }}$ edition, Wiley, New York.

Grove, 2008, The Grove encyclopaedia of materials and techniques in art, G. W. R. Ward (ed.), Oxford.

Guy J., 2007, La escultura en los templos Indios: el arte de la devoción, Fundación La Caixa, Barcelona.

Lamotte É., 1970, Le Traité de la grande sagesse de Nāgārjuna, Université de Louvain, Louvain, Belgique.

Marshall J., 1951, Taxila, vol. III, Plates, Cambridge University Press, Cambridge.

Massoudi O. K. (ed.), 2011, Mes AynakRecent Discoveries Along the Silk Road, exhibition catalogue, National Museum of Afghanistan, Köln.

Middleton A. P., Gill A. J., 1996, “Technical Examination and Conservation of the Stucco Sculpture", in W. Zwalf (ed.), A catalogue of the Gandharan Sculpture in the British Museum, vol. 1, App. 4, British Museum Press, London, p. 363-368.

Miliani C., Rosi F., Daveri A., Brunetti B. G., 2012, "Reflection infrared spectroscopy for the non-invasive in situ study of artists' pigment", Applied Physics A, 106, p. 295-307.

Monico L., Rosi F., Miliani C., Daveri A., Brunetti B. G., 2013, "Non-invasive identification of metal-oxalate complexes on polychrome artwork surfaces by reflection mid-infrared spectroscopy", Spectrochimica Acta, 116, p. $270-280$.

Montana G., Ronca F., 2002, “The 'recipe' of the stucco sculptures of Giacomo Serpotta", Journal of Cultural Heritage, 3, p. 133-145.

Østergaard J. S., 2008, “Emerging Colors: Roman Sculptural polychromy Revived”, in Panzanelli R. (ed.), The Color of Life, J. Paul Getty Museum, Los Angeles.

Pannuzi S., Talarico F., Guida G., Rosa C., 2019, "Polychromy and gilding in the Gandharan sculptures from Pakistan and Afghanistan: samplings from Museum Guimet in Paris, Civic Archaeological Museum of Milan and Museum of Oriental Art of Turin", in S. Pannuzi, L. M. Olivieri (eds.), Restauro Archeologico, vol. 27, issue 1.

Reedy C. L., 1997, "Technical studies of Gandharan art", in R. Allchin, B. Allchin, N. Kreitman, E. Errington (eds.), Gandharan art in context: east-west Exchanges at the crossroads of Asia, The Ancient India and Iran Trust, Cambridge, p. 267-283.

Rhi J., 2006, "Bodhisattvas in Gandharan Art: An Aspect of Mahayana in Gandharan Buddhism", in P. Brancaccio, K. Behrendt (eds.), Gandharan Buddhism, UBC Press, p. 151182.

Rosi F., Daveri A., Doherty B., Nazzareni S., Brunetti B. G., Sgamellotti A., Miliani
C., 2010, "On the use of overtone and combination bands for the analysis of the CaSO4-H2O system by midinfrared reflection spectroscopy", Applied Spectroscopy 64, p. 956-963.

Simpson St J., Ambers J., Verri G., Deviese T., Kirby J., 2012, "Painted Parthian stuccoes from southern Iraq", in P. Brancaccio, K. Behrendt (eds.), Proceedings of the 7th International Congress on the Archaeology of the Ancient Near East, The British Museum and UCL, London, vol. 2, 12-16 April 2010, Harrassowitz Verlag, Wiesbaden, p. 209-220.

Stoler Miller B., 1983, Exploring India's sacred art: selected writings of Stella Kramrisch, University of Pennsylvania Press, Philadelphia.

Talarico F., Biocca P., Sidoti G., Torre M., 2015, "Caratterizzazione delle policromie delle sculture del Gandhara", in S. Pannuzi (ed.), Gandhara: tecnologia, produzione e conservazione, Gangemi Editore, Roma, p. $52-60$.

Tarzi Z., 1986, "La technique du modelage en argile en Asie centrale et au nordouest de l'Inde sous le Kouchans : la continuité malgré les ruptures", Ktema, 11, p. 55-93.

Torraca G., 2009, Lectures on material science for architectural conservation, The Getty Conservation Institute, Los Angeles.

Varma K. M., 1983, Stucco in India: From PreMohenjodaro Times to the Beginning of the Christian Era, Motilal Banarsidass Publishers Pvt. Ltd.

Varma K. M., 1987, Technique of Gandharan and Indo-Afghan stucco images including images of gypsum compound, Motilal Banarsidass Publishers Pvt. Ltd.

Verri G., Saunders D., 2014, "Xenon flash for reflectance and luminescence (multispectral) imaging in cultural heritage applications", The British Museum Technical Bulletin, 8, p. 83-92.

Vitruvius, 1914, Ten Books on Architecture, M. H. Morgan (tr.), Harvard University Press, Book VII, ch. 3, par. 7 .

Weir C. E., Lippincott, E. R., 1961, "Infrared studies of aragonite, calcite, and vaterite type structures in the borates, carbonates, and nitrates, Journal or Research of the National Bureau of Strandards", Applied Physics and Chemistry, vol. 65A, n 3, p. 173-183.

Winckelmann, J. J. [1764], 1856, Geschichte des Kunst des Alterthums (Dresden 1764), The History of Ancient Art (tr. Lodge G. H.), Boston.

Unpublished documents

V\&A, 1931, R. P. 1931/6144 in nominal file MA/1/S2887 Spink and Son Ltd Part 2 1911-1965 at the Victoria and Albert Museum.

V\&A, 2017, Conservation Studio record at the Victoria and Albert Museum. 